\title{
A job profile of home helps in the Netherlands
}

\author{
S. E. J. Arts, MSc ${ }^{1}$, A. Kerkstra, $\mathrm{PhD}^{1}$, H. Huyer Abu-Saad, PhD, RN ${ }^{2}$, J. van der Zee and $\mathrm{PhD}^{1}$ \\ ${ }^{1}$ NIVEL (Netherlands Institute of Primary Health Care), Utrecht, the Netherlands, ${ }^{2}$ University of Maastricht, Faculty of \\ Health Sciences, Department of Nursing Science, the Netherlands
}

\section{Correspondence}

Mrs S.E.J. Arts

NIVEL

PO Box 1568

3500 BN Utrecht

the Netherlands

\begin{abstract}
Owing to many developments and changes in home care in the Netherlands, a national study on home help services was carried out. One of the aims was to examine the job content of the six new categories of home help, the differences in their work and the correspondence of daily practice with formal job descriptions. Six home help categories were examined: alpha helps; A home helps; B caring helps; C and D carers; and specialized E carers - self-registration forms and weekly reports were used for datacollection. For a period of 4 weeks, 458 home helps recorded on these forms all the activities they carried out during and outside home visits. The daily work of alpha helps, A home helps and B caring helps mainly involves housework and psycho-social/supportive activities, whilst B caring helps also carry out some personal care and $\mathrm{C}$ carers do some housework, personal care and psycho-social or supportive activities. The main work of $\mathrm{D}$ carers consists of personal care and psycho-social activities. Psycho-social activities are mainly carried out by specialized E carers, who also do housework, mostly together with the client. In daily practice, the four subordinate categories of home help carry out more psycho-social and reporting activities, and the three highest categories do more housework compared with their formal job descriptions. There also appears to be an overlap in the work of A home helps and B caring helps and in the work of $\mathrm{C}$ and $\mathrm{D}$ carers. An adjustment to formal job descriptions relating to the daily practice of home helpers is required, as well as more time for the extra activities home helps have to carry out. Finally, the overlap between various categories of home helps needs to be resolved whereby instead of six categories of home help, four new categories should be created.
\end{abstract}

Keywords: home help services, home helps, job content, the Netherlands

\section{Introduction}

In the Netherlands, home help services and home nursing services are provided in the border area of social services and health services (Hutten \& Kerkstra 1996). At first, home help services were mainly focused at temporary help for the housewife and her family, only at a later stage being provided for elderly and chronically ill people (Handboek Gezinsverzorging 1989, Maessen 1989, Howe et al. 1990, Jamieson 1991, Hennessy-OECD 1996). Today, home help services includes help of a domestic and caring nature, occasionally supplemented by personal and psycho-social or supportive services. Home help services are offered to the population of the Netherlands who need minor domestic services because of illness, convalescence, old age, handicap, death, psycho-social, and personal problems that threaten the maintenance of the household. Its objectives are to support families and individuals in need and enable them to live as independently as possible in their own homes (Van den Heuvel \& Gerritsen 1991).

As in other European countries, one of the important factors in Dutch health care is the ageing population: the proportions of people aged 65 or over and 
people aged 80 or over are increasing (OECD 1990, Hutten \& Kerkstra 1996). At the same time, in order to save costs and to allow people to remain at home as long as possible, there is a policy of substitution of home care for institutional care (Walker 1991, Nijkamp et al. 1991, Hutten \& Kerkstra 1996). Further, there are health care budget cuts. These three factors together cause long waiting lists in home help services (Hutten \& Kerkstra 1996). Consequently, home care organizations have had to work more efficiently. Two solutions were tried for this problem. First, the integration of organizations for home nursing and home help services were integrated as home care organizations, resulting in a substitution of home help services for home nursing. This integration process was assumed to improve the quality of care and to reduce costs of home care (Ministry of Well-being, Health \& Culture 1990). In 1990, the umbrella organizations for home nursing and home help services merged, and in 1992 the first individual organizations started the integration process. Although in the last years, efficiency in home care has improved, partly because of the substitution of tasks of home helps for tasks of home nurses, the quality of care has not improved, and in some cases even become worse (de Bruin et al. 1996). The second solution was differentiated practice, a clear distinction in the work between the various categories of home help. Besides achieving a more efficient way of working, it also gave home helps more varied opportunities, and thus more personal development. It was thus intended to improve the image of what is perceived as a rather unattractive profession with few prospects.

A few years ago, the general categorization of home helps was replaced by a more detailed categorization. In 1993, with the then new Collective Labour Agreement, new job designations for home helps were introduced. They were based on a job evaluation study in home help services, carried out by the KMPG-consultancy (Welschen et al. 1990), amongst others. Since then, six categories of home help have been distinguished: alpha help; A home help; B caring help; C carer; D carer; and specialized E carer. Each category has its own task profile and (training) qualifications (AbvaKabo - Union for Public Sector Workers - 1994). In framework I below, an overview of the six categories of home help is given:

Home helps in the Netherlands (situation at the time of the research)

The SOGW Working Group developed a job description for caring and home help staff in 1992. The four main categories of activity are housework, caring, psycho-social/supportive activity, and consultation and co-operation (Working Group SOGW 1992). This work is done by a wide variety of workers. New job designations for home helps were introduced with the new Collective Labour Agreement for 1993. Since then, six types of home helps have been distinguished: alpha help, home help A, caring help B, C carer, D carer, and specialized $\mathrm{E}$ carer. These various types of home help also have their own task profiles (AbvaKabo 1994), based on the above-mentioned job description (Working Group SOGW 1992). The (training) qualifications are also given for every type of home help (Union for Public Sector Workers: AbvaKabo 1994).

- Alpha helps were introduced in 1973, as a way of providing cheaper help. The alpha helps are not employed by the organizations, but in formal terms, the client is their direct employer. Most organizations operate as an intermediary between the client and the alpha help. The task of an alpha help is to support the client in doing daily or weekly housework, which the client can either not do or not do alone. Alpha helps have no opportunity of contact with colleagues; and notify their intermediaries in case of major changes or problems. There are no specific qualifications for an alpha help.

- A home helps mainly do housework, of which nature, content and frequency are stable. They follow an individual care plan. The home help A also has periodical contact with colleagues and supervisor. This job requires some years of domestic science as a school subject and recently an in-service qualification (certificate home help A) has also been required.

- B caring helps provide some personal care, limited in time and type in addition to housework. The nature, content and frequency of the activities are more or less stable. B helps follow an individual care plan and can make minor alterations in this plan. Besides periodical contact with colleagues and supervisor, B helps also have occasional contact with other professional care-givers. B helps need a home help certificate or a caring help B certificate (via inservice education).

- C carers are mainly involved in caring activities and some housework, but only limited in time. They carry out these activities partly using their own judgement and change the plans independently. The client situations are often unstable. Like the B helps, C carers, apart from the fixed meetings with colleagues and the supervisor, only have infrequent contact with other care-givers. A carer certificate or an auxiliary nurse certificate is required for both the carers-functions (C and D).

- D carers are largely concerned with caring and psychosocial issues, the nature, content and frequency of which vary considerably. They plan their work using their own judgement and initiative and are able to deviate from fixed programs. In addition to regular meetings with colleagues and the supervisor D carers maintain regular contact with other professional care-givers. 
- Specialized E carers support households with multiple complex problems, related to the client's behavioural change. They also do housework and caring activities. The nature, content and frequency of the activities are strongly affected by the instability of the client situation. The specialized E carers plan their work using their own judgements and initiative and are able to deviate from fixed programs. Their activities are systematically adjusted to other professional caregivers, with whom they are in frequent contact. A carer certificate and a specialized home certificate are required for this position.

The five types of traditional home helps also observe potential changes in the client situation and report these to their supervisor (Union for Public Sector Workers: AbvaKabo 1994).

A schematic description of the different job profiles for the six types of home help is presented in Table 1. It shows that alpha helps and A home helps are restricted to housework; B caring helps do the housework and give some personal care; $\mathrm{C}$ carers are mainly involved in providing personal care and some housework; D carers mostly carry out personal care and psycho-social or supporting tasks, and specialized E carers support households with multiple complex problems.

Apart from the work home helps carry out during home visits, they spend time on travelling and other activities such as team meetings, planning, courses, working in day-care, training and education, supervising activities and administrative work (not in included in the table).

Before looking at the situation in other European countries, we give an overview of home help services in The Netherlands (the provision, organization and financing, and manpower) in the following, framework II:

Home help services in the Netherlands (situation at the time of the research)

Organizations for home help services. Home help services are provided either by home help organizations or by home care organizations (integrated organizations for home help services and community nursing). These are mainly non-profit organizations. However, there are also private profit-making organi- zations who provide home help and this number is increasing. In this study, only non-profit organizations participated.

Financing. Home help organizations are about $90 \%$ funded through a system of subsidies based on the General Act on Exceptional Medical Expenses (AWBZ). Under the provisions of this Act, all inhabitants of the Netherlands are entitled to receive home help and no formal referral is needed. An income related co-payment of DFL 10.00 per hour is required in the costs of home help services. The maximum amount of co-payment per week depends on the client's income and varies between DFL 4.50 and DFL 250.00 per week (per $1 / 7 / 1994)$. The clients of alpha helps have to pay them directly per hour (DFL 14.60).

Provision of services. As mentioned above, no formal referral is needed for home help, so potential clients can contact the home help services by themselves. Sometimes the first contact is made by a GP, family member or other professional care-giver. After the first contact, an assessment of needs is done by someone who is not involved in direct care. Then, the care is allocated by a home help organizer. Finally, the actual care is provided by the earlier mentioned categories of home help.

Manpower. In 1995, almost 110000 people were working in home help services and 35000 fulltime equivalents (FTEs). These numbers are as follows divided over the six categories of home help and home help organizers (Baars \& Spaan 1997, van der Windt et al. 1997):

36833 alpha helps and 4899 FTEs

32938 A home helps and 11157 FTEs

14438 B caring helps and 6817 FTEs

$13698 \mathrm{C}$ carers and 6846 FTEs

5510 D carers and 2505 FTEs

1354 specialized E carers and 876 FTEs

3302 home help organizers and 2293 FTEs

The problems which Dutch home help services are facing are not restricted to the Netherlands, but also arise in other countries of the European Union where there are similar organizations for home help services. In most countries, home help services belong to the social services, are organized by and fall under the

\begin{tabular}{lllll}
\hline $\begin{array}{l}\text { Category of } \\
\text { home help }\end{array}$ & Housework & Caring & $\begin{array}{l}\text { Psycho-social/ } \\
\text { supportive }\end{array}$ & $\begin{array}{l}\text { Co-operation and } \\
\text { consultation }\end{array}$ \\
\hline $\begin{array}{lllll}\text { Alpha help } \\
\text { A home help }\end{array}$ & $\times$ & & & \\
B caring help & $\times$ & & & \\
C carer & $\bigcirc$ & $\times$ & & \\
D carer & $\times$ & $\times$ & $\bigcirc$ & $\times$ \\
Specialized E carer & $\bigcirc$ & $\bigcirc$ & $\times$ & \\
\hline
\end{tabular}

Table 1 Formal task profile for each category of home help

$X=$ main tasks; $\bigcirc=$ secondary tasks. Source: AbvaKabo 1994. 
responsibility of the local authorities. Belgium, France, Italy and Portugal have a mixture of organizations operated by municipalities and private organizations. Germany and Ireland are the only countries, besides the Netherlands, where home help services are part of the health care system (Hutten \& Kerkstra 1996).

Direct help to the clients is provided by various categories of home help: home and family helps, homemakers, home carers, social workers, care attendants, and other personnel trained for home helping tasks. In general, home helps have no formal training, but there are a few short courses and some 'training on the job'. Only in Belgium, Germany, Italy, Sweden, and for the most part in Finland do home helps receive specific training, varying from 6 months to 3 years. This is also true to a small extent in the Netherlands. In many European countries there is a shortage of home helps. Experts in these countries say that the profession is considered unattractive, because it has a low status, it is poorly paid and the training is considered to be inadequate (Hutten \& Kerkstra 1996). The main tasks of European home helps are housework, personal care, and general support. Sometimes they also provide moral support with psycho-social problems and stimulate informal care (Hutten \& Kerkstra 1996).

In most European countries there is a distinction in the work of the various categories of home help. With regard to Dutch home help services, it is expected that in daily practice the distinction in the work of the six categories of home help is as evident as it is in theory.

The division of tasks and time over six categories of home helps in daily practice in the Netherlands had not been studied before. Therefore, an extensive description of the work of home helps in the Netherlands was the objective of this study. The study addresses the following question: to what degree do formal job descriptions and job profiles of home helps in the Netherlands correspond with the daily practice in home help services?

In order to answer this question, two further questions have to be answered: first, how do the various categories of home help spend their working time? and secondly; how are the activities in the four main categories of working in home help services carried out by the six categories of home helps during the home visits and in what way do the activities of the various categories of home help differ?

\section{Methods}

\section{Sample}

A two-stage sampling method was used to obtain a representative sample of home helps: first the organizations and then the home helps. For the organiza- tions, three stratification criteria were used: region (the four regions north, south, east and west); integration process of the home help organization (integrated with home nursing or not) and catchment area of the organization (care provided in an area including a city of more than 100000 thousand inhabitants or not). This resulted in a matrix of 16 cells, containing all the 104 organizations for home help services in the Netherlands. From each cell, one organization was randomly selected and asked to participate in the study. If an organization did not want to participate, another organization from the same cell was asked. In total 30 organizations were asked to participate.

Each organization was to recruit 30 home helps equally divided over the six categories of home helps, as described above. There was one inclusion criterion for home helps: they should have been in service for at least 1 month. A total of 510 home helps (one organization participated with two teams) were expected to take part in the study.

\section{Procedure}

During an initial meeting the purpose of the study was explained to the home helps and all forms that had to be used were clarified fully. The home helps were asked to record the activities they carried out during all home visits on separate forms over a 4-week period and to fill in a report at the end of each week, recording all activities additional to the home visits. The recorded periods for the 16 organizations were divided over 8 months for practical reasons and to minimize the effect of possible seasonal fluctuations.

\section{Instruments}

\section{Registration form}

Home helps spend most of their time on home visits. In order to gain a representative picture of these activities, home helps recorded their work after every home visit. A self-registration form was developed for this. The form is based on the descriptive model for working in home helps services (Arts et al. 1997). In this model a distinction is made between the four main categories of work in home help services highlighted earlier (framework I). The form specifies each of the four main categories in sub-categories and activities: housework with 30 activities, personal caring with 22 activities, psycho-social activities with 40 activities (including four social activities) and 18 reporting activities. This categorization is based on existing task profiles and classifications, and existing assessment forms used in home help services (Working Group SOGW 1992, AbvaKabo 1992, Stichting Thuiszorg Hilversum, 's Graveland \& 
Loosdrecht 1992; Verheij et al. 1993, AbvaKabo 1994). A pilot study was carried out to test the inter-raterreliability of the form (Arts et al. 1996). The level of agreement, i.e. the similarity between the frequencies scored by the home helps and the frequencies scored by the observer expressed in percentages, was computed for every activity, sub-category and main category. When the frequencies are equal, the level of agreement is $100 \%$. In general, the items on the registration form were scored reliably, and the reliability scores of the main categories varied between $94 \%$ and $98 \%$. A few home helps made remarks regarding the content-validity of the registration form, such as 'the registration form is clearly and conveniently arranged, but not comprehensive enough'. The relevant remarks were taken into account with the final version of the registration form. The results of this study showed that the self-registration form is a reliable and valid instrument in assessing the daily practice in home help services, representing virtually all activities that home help services may provide (Arts et al. 1996). Additionally, the home helps recorded on the registration form both the time spent on the four main categories and the travelling time between clients and between clients and the organization.

\section{Weekly report}

For all other activities, a so-called weekly report was developed. Activities outside the home visits, like planning and meetings, and the time spent on these activities were recorded on this form. The home helps were also able to note additional activities that had been carried out, like training, administrative work, and absence due to illness or to holidays.

\section{Analyses}

Because of the nature of this paper, mainly descriptive analyses were used: (frequencies) means, standard deviations, and in some tables confidence intervals (CI). Analysis of variance (ANOVA) was used to test if there were significant differences between the mean number of activities carried out by the six categories of home helps for the main categories of work (Norusis 1992).

\section{Results}

\section{Response}

Thirty organizations for home help or home care were asked to participate in the study. Fourteen organizations declined to take part. The main reasons for not participating were lack of time due to reorganization or merger (6) or involvement in other research (8). Finally, 16 organizations (53\%) took part in the study, one organization participated with two teams.

Each organization was expected to select 30 home helps, five of each of the six categories of home help (510 home helps). Not all organizations though were able to select these 30 home helps, because there were not always five home helps in each category, nor were all six categories of home help present or available in the organization. At first, 474 home helps (93\%) were selected to participate in the study. As a result primarily of illness or holidays, 458 home helps remained $(97 \%)$ to record their activities for almost 16000 home visits.

Table 2 shows the distribution of the home helps over the six categories, the corresponding number of completed registration forms per category and the average number of registration forms completed per home help per category during the registration period.

Almost all (97\%) of the home helps were women. The mean age of the home helps was 39 years with a standard deviation of 9.9, and the average hours worked per week were 20 (standard deviation of 10).

Instead of 1832 weekly reports (i.e. when 458 home helps each return 4 weekly reports), the home helps returned 1784 weekly reports (97\%). Thirty-two home helps sent back three instead of four weekly reports, and eight home helps sent back two instead of four. The majority of non-responses can be explained by a failure to return the weekly reports during holidays or illness. Some bias may therefore have occurred in the figures for holidays and illness. Sometimes people for-

\begin{tabular}{lccc}
\hline $\begin{array}{l}\text { Category of } \\
\text { home help }\end{array}$ & $\begin{array}{l}\text { No. of } \\
\text { home helps }\end{array}$ & $\begin{array}{l}\text { No. of } \\
\text { registration forms }\end{array}$ & $\begin{array}{l}\text { Average No. of registration } \\
\text { forms per home help }\end{array}$ \\
\hline Alpha help & 73 & 569 & 7.8 \\
A home help & 88 & 1623 & 18.4 \\
B caring help & 87 & 2125 & 24.4 \\
C carer & 81 & 3364 & 41.5 \\
D carer & 75 & 6845 & 91.3 \\
Specialized E carer & 54 & 1393 & 25.8 \\
Total & 458 & 15921 & 34.8 \\
\hline
\end{tabular}

Table 2 Distribution of home helps over the six categories of home helps, the corresponding number of registration forms and the average number of registration forms per category of home help 
got to send the reports back, particularly at the end of the recording period.

Time spent on the various activities by home helps

The total amount of time comprises the duration of the home visits, the travelling time between clients and between clients and the organization, the time spent on meetings and the time spent on additional activities (training, working in day-care (caring for and looking after elderly, who normally live at home or in a centre during the daytime) or administrative work). The time home helps were absent due to illness or holidays was noted, but not included in this overview of actual working time. Table 3 shows that the distribution differs for every category of home help: alpha helps spent almost no time outside home visits; D carers travelled the most, due to the relatively short time they spent with the clients and the many clients they visit. The time spent on meetings and additional activities increased with higher categories of home helps and therefore the time spent on home visits decreased.

The majority of time in the four main categories is spent by home help services working during home visits. In all 15921 home visits, the home helps spent on average $38 \%$ of the time on housework, $33 \%$ on personal care and $27 \%$ on psycho-social activities. Only $2 \%$ of the time is spent on reporting.

Figure 1 shows the distribution of time during home visits for each of the six categories of home helps. Like the alpha helps, A home helps and B caring helps spent the majority of their time on housework. All three categories also spent some time on psychosocial activities. $C$ carers spent their time more or less equally distributed over housework, personal care and psycho-social activities. D carers spent half of their time on personal care, and also some time on psychosocial activities. Specialized E carers spent almost half of their time on psycho-social activities, and another large part of the time on housework, usually carried out together with the client. All home helps spent only a little time on reporting.

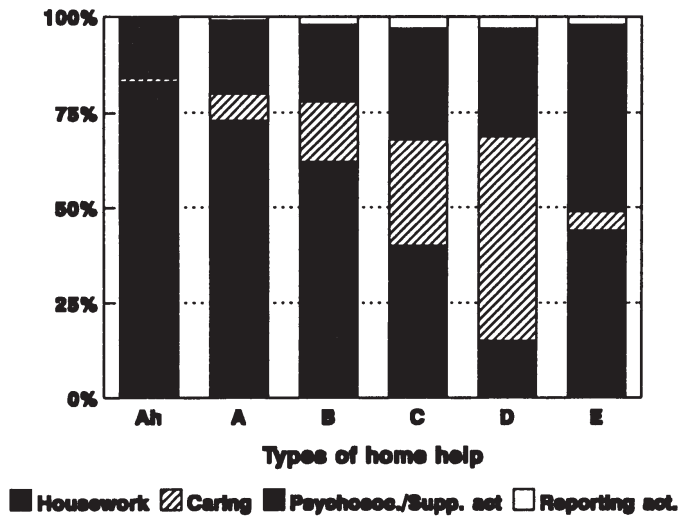

Figure 1 Time spent on the four main categories of working by home help services (in percentages for each category of home help).

The home helps were asked whether they participated in one or more meetings during the registration period. Three-quarters of the home helps $(n=344)$ indicated that they had participated in one or more meetings during 4 weeks (Table 4). The total average time that was spent on meetings was $4 \mathrm{~h}$ and $45 \mathrm{~min}$, increasing with higher categories of home help.

Almost all meetings were together with colleagues and supervisors. Occasionally other professional caregivers, such as GPs or other relevant people, such as informal care-givers, were at these meetings. The most commonly discussed subjects were the weekly plans, clients, and the functioning of the group or team. The majority of the home helps indicated that there was enough time in their planning for these meetings.

Almost half of the home helps $(n=227)$ carried out additional activities during 1 or more weeks of the study period, besides home visits and meetings. The most frequently occurring activities were those for training programs, and planning and co-ordinating activities. Most time-consuming was Ôworking in day-care centres'. The time spent on additional activities increased with higher categories of home help.

Table 3 Distribution of time spent by the six categories of home help

\begin{tabular}{lcccccc}
\hline Home helps activities & Alpha $(n=73)$ & $\mathrm{A}(n=88)$ & $\mathrm{B}(n=87)$ & $\mathrm{C}(n=81)$ & $\mathrm{D}(n=75)$ & $\mathrm{E}(n=54)$ \\
\hline Home visits & $97.5 \%(4.1 \%)$ & $91.4 \%(7.8 \%)$ & $89.4 \%(9.9 \%)$ & $84.3 \%(2.5 \%)$ & $74.6 \%(12.8 \%)$ & $76.3 \%(14.6 \%)$ \\
Travelling time & $1.6 \%(3.1 \%)$ & $2.9 \%(5.1 \%)$ & $2.5 \%(2.4 \%)$ & $3.8 \%(3.4 \%)$ & $11.4 \%(6.3 \%)$ & $4.2 \%(2.7 \%)$ \\
Meetings & $0.3 \%(1.1 \%)$ & $3.6 \%(4.3 \%)$ & $4.5 \%(3.6 \%)$ & $6.4 \%(4.7 \%)$ & $7.7 \%(6.6 \%)$ & $10.8 \%(8.8 \%)$ \\
Additional activities & $0.6 \%(2.3 \%)$ & $2.1 \%(5.0 \%)$ & $3.6 \%(8.2 \%)$ & $5.5 \%(0.8 \%)$ & $6.3 \%(8.8 \%)$ & $8.7 \%(11.9 \%)$ \\
Total time spent & $100 \%$ & $100 \%$ & $100 \%$ & $100 \%$ & $100 \%$ & $100 \%$ \\
\hline
\end{tabular}

Means and standard deviations in percentages. 
Finally, home helps also indicated on the weekly report if they had been absent due to illness or holidays. About one-fifth of the home helps had been ill during the study period. The duration of their absence varied from 1 day to 4 weeks. One-third of the home helps had a holiday during that period, varying from 1 day to 3 weeks.

\section{Distribution of the activities over the main categories of working in home help services}

Table 5 shows, per category of home help, the distribution of all activities performed in 15921 home visits, over the five categories of work: housework, personal care, social, psycho-social and reporting activities. A distinction is made between social activities like chatting or asking after a client's situation or condition and real psycho-social support.
For each home visit, the number of activities for each of the five categories of work carried out was calculated. In the next step, the data were aggregated from the home visit level to the level of home help. Table 5 shows the mean number of activities carried out during the 15 921 home visits by the six categories of home help.

Table 5 shows that housework was the main activity of alpha helps, A home helps and B caring helps. Specialized E carers also did housework, but performed these activities often together with the client instead of taking over from the client. As expected, D carers, and B and $C$ carers to a lesser degree performed much personal care. Compared with other home helps, D carers carried out the least social activities. Psycho-social activities were carried out mainly by specialized $\mathrm{E}$ carers, and by $\mathrm{C}$ carers to a lesser degree. Both $\mathrm{C}$ and $\mathrm{D}$ carers performed most reporting activities. Specialized E carers

\begin{tabular}{|c|c|c|c|c|c|}
\hline \multirow{2}{*}{$\begin{array}{l}\text { Category of } \\
\text { home help }\end{array}$} & \multirow{2}{*}{$\begin{array}{l}\text { Number of } \\
\text { home helps } \\
\text { participating in } \\
\text { meetings }\end{array}$} & \multicolumn{2}{|c|}{$\begin{array}{l}\text { Average time spent } \\
\text { in } \mathrm{h} \text { and } \mathrm{min}\end{array}$} & \multicolumn{2}{|c|}{$\begin{array}{l}\text { Standard deviation } \\
\text { Standard deviation } \\
\text { in } \mathrm{h} \text { and } \min \end{array}$} \\
\hline & & $\mathrm{h}$ & $\min$ & $\mathrm{h}$ & $\min$ \\
\hline Alpha help & $7 \%$ & 1 & 43 & & 57 \\
\hline A home help & $75 \%$ & 2 & 21 & 1 & 28 \\
\hline B caring help & $82 \%$ & 3 & 41 & 2 & 17 \\
\hline C carer & $100 \%$ & 4 & 34 & 2 & 43 \\
\hline D carer & $88 \%$ & 5 & 54 & 4 & 51 \\
\hline Specialized E carer & $100 \%$ & 7 & 54 & 4 & 31 \\
\hline Total & 344 & 4 & 45 & 3 & 49 \\
\hline
\end{tabular}

Table 4 Percentage of home helps participating in meetings during the registration period (4 weeks)

$(n=344)$ : the average time spent and standard deviations for each category of home help.

Table 5 Mean number of activities carried out during home visits per main category by the six categories of home help

\begin{tabular}{|c|c|c|c|c|c|c|c|c|}
\hline Home helps & Alpha $(n=73)$ & $\mathrm{A}(n=88)$ & $\mathrm{B}(n=87)$ & $\mathrm{C}(n=81)$ & $\mathrm{D}(n=75)$ & $\mathrm{E}(n=54)$ & & \\
\hline Number of home visits & $(569)$ & $(1623)$ & (2125) & (3364) & $(6845)$ & (1393) & $\mathrm{F}-$ ratio & $P$ value \\
\hline \multicolumn{9}{|l|}{ Housework } \\
\hline Mean - s.d. & $9.9(3.1)$ & $9.4(4)$ & $8.6(3.2)$ & $6.7(3.5)$ & $1.5(1.7)$ & $4.7(2.2)$ & 78.8 & $<0.001$ \\
\hline Confidence interval & $9.2-10.6$ & $8.5-10.2$ & $7.9-9.2$ & $5.9-7.5$ & $1.1-1.9$ & $4-5.3$ & & \\
\hline \multicolumn{9}{|l|}{ Personal care } \\
\hline Mean_s.d. & $0.1(0.2)$ & $0.4(1)$ & $1.1(1.3)$ & $2.2(2)$ & $3.2(1.3)$ & $0.4(0.6)$ & 71.7 & $<0.001$ \\
\hline Confidence interval & $0.02-0.1$ & $0.2-0.6$ & $0.9-1.4$ & $1.8-2.7$ & $2.9-3.5$ & $0.3-0.6$ & & \\
\hline \multicolumn{9}{|l|}{ Social activities } \\
\hline Mean - s.d. & $2.3(0.8)$ & $2.2(0.7)$ & $2.2(0.7)$ & $2.1(0.6)$ & $1.7(0.6)$ & $2.3(0.7)$ & 7.9 & $<0.001$ \\
\hline Confidence interval & $2.1-2.5$ & $2-2.3$ & $2-2.3$ & $2-2.2$ & $1.5-1.8$ & $2.1-2.5$ & & \\
\hline \multicolumn{9}{|c|}{ Psycho-social/supportive activities } \\
\hline Mean - s.d. & $3.1(3.2)$ & $3.8(3.2)$ & $4.4(2.9)$ & $5.1(3.3)$ & $3(2.4)$ & $8.4(4.3)$ & 23.7 & $<0.001$ \\
\hline Confidence interval & $2.3-3.8$ & $3.1-4.4$ & $3.8-5$ & $4.3-5.8$ & $2.4-3.6$ & $7.2-9.6$ & & \\
\hline \multicolumn{9}{|l|}{ Reporting activities } \\
\hline Mean - s.d. & $0.02(0.1)$ & $0.3(0.8)$ & $0.5(0.7)$ & $0.7(0.9)$ & $0.7(0.8)$ & $0.4(0.8)$ & 9.5 & $<0.001$ \\
\hline Confidence interval & $0-0.05$ & $0.1-0.4$ & $0.3-0.6$ & $0.5-0.9$ & $0.5-0.9$ & $0.2-0.7$ & & \\
\hline
\end{tabular}

Standard deviation and confidence intervals with accompanying F-ratio's and P values $(n=458)$. 
reported less during the home visits than other carers, probably because they spent a lot of time on meetings and consultation outside the home visits (see Table 4).

At the beginning of the paper, it was assumed that the various categories of home helps had dissimilar task profiles, and therefore did different work. With the results obtained in this study, this assumption was tested with an analysis of variance test. The last two columns in Table 5 (F-ratio and significance-level) show that the job content of the six categories of home helps indeed differs significantly $(P<0.001)$. With regard to housework, $\mathrm{C}, \mathrm{D}$ and $\mathrm{E}$ carers did significantly fewer activities compared with alpha helps, A and B helps. On the other hand, B, C and D carers performed significantly more personal care. Social activities like informal chats, were carried out significantly less by $\mathrm{D}$ carers compared with the other five categories of home help. Psycho-social activities were carried out significantly more by specialized $\mathrm{E}$ carers and $\mathrm{C}$ carers to a lesser degree. Both $C$ and $D$ carers, and $B$ and $E$ carers to a lesser degree, reported significantly more compared with the subordinate categories of home help.

Based on the assessment of their daily practice in home help services, both the activities carried out and the time spent on it, a new task profile of the six categories of home help was created (Table 6).

\section{Correspondence of formal job descriptions and task profiles with daily practice in home help services}

To examine whether the home helps do the work they are supposed to do, two task profiles (Tables 1 and 6) were compared. The two schemes differ for all six categories of home help: the differences are presented in Table 6 in brackets. Three main differences were found. First, the practice findings show that the four subordinate categories of home help perform more psychosocial tasks than prescribed in their job description and D carers perform less of these activities. Secondly, in daily practice, the three higher categories of home help carry out more housework than they are supposed to do. Finally, B caring helps and C carers performed more in the area of co-operation and consultation than is described in their formal task profiles.

\section{Discussion}

This study was carried out to gain insight into the work, time and activities, of home helps in Dutch home help services. As a result of recent developments and changes in health care and particularly in home care, which were mentioned in the introduction, home care organizations have had to work more efficiently and improve quality of care at the same time. Other developments like the implementation of personal budgets for special groups of clients, and the increasing number of private home care organizations, only emphasize the need for increasing efficiency and quality of care.

Based on the activities home helps carry out and on the time spent on these activities, a new profile set for home helps had to be developed. With regard to the new task profiles, two main conclusions can be drawn. The first is that the new task profiles show rather large differences between formal task profiles and daily practice, especially for psycho-social activities. For a better adjustment to the daily practice, time has to be reserved during the assessment of needs procedure for psycho-social support (for example by $10 \%$ ). This kind of support is always given to a client following the home helps professional performance. Secondly, explicit attention should be paid to (hidden) psychosocial needs of clients. By taking into account psychosocial support during the assessment of needs as well as during the allocation of help, the extra activities home helps carry out in this area will be limited, both in duration and quantity. This will probably increase the efficiency of the work. Efficiency can also be increased by providing the home helps more authority on assessment and re-assessment procedures. They should be able to introduce minor changes in the care plan based on a changing client situation.

\begin{tabular}{lllll}
\hline & Housework & Caring & Psycho-social & $\begin{array}{l}\text { Cooperation and } \\
\text { supportive consultation }\end{array}$ \\
\hline Alpha help & $\times$ & & $\bigcirc(++)$ & \\
A home help & $\times$ & $\bigcirc(++)$ & $\bigcirc(++)$ & \\
B caring help & $\times$ & $\bigcirc$ & $\times(++)$ & $\bigcirc(++)$ \\
C carer & $\times(+)$ & $\times$ & $\times(++)$ & $\bigcirc(++)$ \\
D carer & $\bigcirc(++)$ & $\times$ & $\bigcirc(-)$ & $\bigcirc$ \\
Specialized E carer & $\times(+)$ & $\bigcirc$ & $\times$ & $\times$ \\
\hline
\end{tabular}

Table 6 Task profile for each category of home help based on daily practice

$X=$ main tasks; $\bigcirc=$ secondary tasks $;++=$ done, but not described in formal task profile; $+=$ done more than described in formal task profile; $-=$ done less than described in formal task profile. 
Consequently, home helps can work more flexibly and therefore more efficiently (Svensson \& Dirks 1996).

An additional factor is the overlap between the consecutive categories of home help with regard to the content of their work (A home helps and B caring helps and $C$ carers and D carers) which is more substantial than appears from the formal job descriptions. Although the work of all six categories of home help showed significant differences, there are no clear boundaries in their work: home helps sometimes carry out activities for which they are not qualified (personal caring and psycho-social activities). This may have a negative effect on the quality of care. This is supported by the studies of Van den Herik et al. (1995) and the Committee for Caring (Commissie Verzorging 1995), the latter being created to formulate an inventory and analyse problems in the area of job development, education and work pressure. They both concluded that the boundaries between the work of the consecutive categories of home helps, except for the specialized E carers, are vague, and appeal for a removal of this overlap.

There is also some overlap in the work of home help services and community nursing services. The boundaries in the work of $C$ and D carers (carers from home help services) and community nurses auxiliaries (community nursing) are not clear either. Both groups are involved in personal care (simple and less complex care), but home help services are aimed at the functioning of the total household whilst community nursing services are aimed at the individual health problem of the client (Jansen \& Kerkstra 1993). Compared with separate organizations for community nursing and home help services, in organizations for home care the overlap between these two groups is less because of substitution of care that took place in the integration process of community nursing and home help services.

The work of specialized E carers and social workers has similarities too: both are involved with clients or families with (multiple) psycho-social problems. The difference here is that the specialized E carer helps clients/families when their problems also have an effect on the household. Re-organization of the household, carried out together with the client, is essential and therefore help is provided at the client's home. The primary tasks of social work, carried out in a social services setting, are among others, guidance and treatment, support and providing information and advice (VOG 1997).

The new profiles also show that housework and personal caring are never carried out alone in home help services, but in combination with at least psycho-social activities (see Table 6). This is also supported by findings from a study by Van den Herik et al. (1995) that showed housework alone is quite exceptional in Dutch home help services. The research findings show that, besides reporting tasks, there are three main tasks: housework, personal care and psycho-social tasks. Four new categories of home help can be distinguished, based on this division and on the fact that housework and personal caring are carried out in combination with at least psycho-social activities. The first category mainly carries out housework and supporting activities, the second category carries out a combination of housework and simple personal caring activities with supporting activities. The third category carries out mainly personal care activities and psycho-social activities, and finally the fourth category with the main task of providing psycho-social guidance for families with multiple-complex problems. All home helps carry out activities in the area of consultation and co-operation (reporting), the higher categories perhaps more so than their subordinate colleagues. This suggestion is being supported by both Van den Herik et al. (1995) and the Committee for Caring (Commissie Verzorging 1995).

\section{Limitations of the study}

The study has some restrictions with regard to the sample of home helps participating.

The way the home helps were selected for the study, either volunteering or being selected by a supervisor, is a possible bias of the total sample of home helps, and did not include home helps on long-term sick leave. Therefore, the results may be too favourable. The number of home helps from each category taking part in the study varied. Of course, the total number of home helps is not equally divided over the six categories (see framework II).

This new classification of categories of home help is based on the tasks Dutch home helps carry out in daily practice. As described previously, these tasks are also carried out by home helps in other countries (Hutten \& Kerkstra 1996). Therefore, this classification is also suitable for home help services in other countries of the European Union (EU). Together with formal and comparable education and training for all categories of home help in the EU, home help hopefully will become a more attractive profession in all member states of the EU. Due to an ageing population and the increasing demand for home care in Europe, home help services are a fundamental part of the health care system. Differentiated practice enables home helps to work with each other and with other professional care-givers, in various client situations. A further substitution of home care for hospital 
care, home helps and especially D carers will fill the gap between these areas.

In future research more attention should be paid to the quality of care provided by home helps and perceived by clients. In addition to the differences found in the job content of the six categories of home help, a new issue was raised: the differences between the six categories of home help regarding job satisfaction, burnout, health and absenteeism.

\section{Acknowledgements}

This research was carried out at the initiative of the Ministry of Public Health, the Professional Association of Home Helps (STING), the Association of Management of Home Help Organizations (STRATEGO) and the Netherlands Institute of Primary Health Care (NIVEL). The study was financed by the National Centre of Nursing \& Caring (LCVV).

\section{References}

AbvaKabo (1992) Overzicht van Verschillende Functies in de Gezinsverzorging (Review of Various Jobs in Home Help Services). OAW: stuknummer 9210220y. 15.4.

AbvaKabo (Union for Public Sector Workers) (1994) Concept CAO-Thuiszorg met Salarisregelingen (Draft Collective Labour Agreement Home Care with Salary-Regulations). AbvaKabo, Utrecht.

Arts S.E.J., Kersten H. \& Kerkstra A. (1996) The daily practice in home help services in the Netherlands: instrument development. Health and Social Care in the Community 4 (5), 280-289.

Arts S.E.J., Kersten J.W.E.T. \& Kerkstra A. (1997) Werken in de Gezinsverzorging (Working in Home Help Services). De Tijdstroom/LCVV, Utrecht.

Baars J.A. \& Spaan J.M. (1997) Jaarboek Thuiszorg 1995 (Home Care Yearbook 1995). LVT/ NZi, Bunnik/Utrecht.

Bruin de A., Ruiter E.C. \& Kerkstra A. (1996) Integratie Kruiswerk en Gezinsverzorging: Meningen en Ervaringen van Hulpverleners en Cli'nten (Integration Cross Work and Home Help Services: Opinions and Experiences of Care-Givers and Clients). NIVEL, Utrecht.

Commissie Verzorging (1995) Zorg voor Zorg (Caring for Care). LCVV, Utrecht.

Handboek Gezinsverzorging (1989/90) Vuga Publikatie, Amsterdam.

Hennessy P. (1996) Caring for Frail Elderly People: Policies in Evolution. Organization for Economic Co-operation and Development (OECD) (Social Policy Studies no. 19): OECD, Paris.

Herik van den C., Been de M. \& Vulto M. (1995) Alles Draait om de Cli'nt: de Inhoud, het Eigene en de Kwaliteit van de Arbeid van het Uitvoerende Werk in de Gezinszorg (Everything Revolves Around the Client: the Content, Characteristic and Quality of Work in Home Help Services). Vakgroep Vrouwenstudies, FSW, RUL, Leiden.

Heuvel van den W. \& Gerritsen H. (1991) Home care services in the Netherlands. In: A. Jamieson (Ed.) Home Care for
Older People in Europe: a Comparison of Policies and Practices. Oxford University Press, Oxford.

Howe A., Ozanne E. \& Selby Smith C. (Eds) (1990) Community Care Policy and Practice: New Directions in Australia. Public Sector Management Institute: Clayton, Victoria.

Hutten J.B.F. \& Kerkstra A. (1996) Home Care in Europe. Arena, Aldershot.

Jamieson A. (Ed.) (1991) Home Care for Older People in Europe: Policies and Practices. Oxford University Press, Oxford.

Jansen P.G.M. \& Kerkstra A. (1993) Functiedifferentiatie binnen de Thuiszorg. De Functies van Wijkverpleegkundige, Wijkverpleegster en Gezinsverzorgende Nader Omschreven (Differentiated Practice in Home Care. the Jobs of Community Nurse, Community Nurse Auxiliary and Home Carer More Precisely Described). NIVEL, Utrecht.

Maessen P.J.J. (1989) Bezuinigingen op de Gezinsverzorging (Budget Cuts in Home Help Services). Rijksuniversiteit Leiden, Leiden.

Ministry of Well-Being Health \& Culture (WVC) (1990) Heroverwegingsonderzoek 'van Samenwerken naar Samengaan': Gezinsverzorging en Kruiswerk naar Een Geïntegreerd Aanbod in De Thuiszorg (Reconsideration-Study from Working Together to Going Together: Home Help Services and Community Nursing to an Integrated Supply in Home Care). Rapport van de heroverwegingswerkgroep doelmatigheidsonderzoek organisatiestructuur gezinsverzorging en kruiswerk. Ministerie van WVC, Rijswijk.

Nijkamp P., Pacolet J., Spinnewyn H., Vollering A., Wilderom C. \& Winters S. (1991) Services for the Elderly in Europe. a Cross-National Comparative Study. HIV/VU: Leuven, Amsterdam.

Norusis M.J. \& /SPSS Inc. (1992) SPSS/PC+ tm Base System User's Guide, version 5.0. SPSS Inc., Chicago.

OECD (1990) Ageing Populations: the Social Policy Implications. OECD, Paris.

Stichting Thuiszorg Hilversum, 's Graveland \& Loosdrecht (1992) Functie Schema Uitvoerenden (Job Schemes for Home Helps). Organisatie voor Gezinsverzorging, Hilversum.

Svensson J.S. \& Dirks J.E.M. (1996) Indicatiestelling en Autonomie: Een Nieuwe Aanpak (Assessment-Procedure and Autonomy: a New Approach). Thuiszorg Centraal Twente/Universiteit Twente Hengelo, Wageningen.

Verheij R.A., Caris-Verhallen W.M.C.M. \& Kerkstra A. (1993) Integratie Kruiswerk en Gezinsverzorging, Ervaringen van Hulpverleners en Cli'nten (Integration Cross Work and Home Help Services: Experiences of Professionals and Clients). NIVEL, Utrecht.

VOG-sectie AMW (1997) Het Algemeen Maatschappelijk Work in Beeld 1995 (An Overview of Social Work 1995). Uitgeverij SWP, Utrecht.

Walker A. (1991) Home Care in Europe: Current Trends and Future Prospects. European Association of Organizations for Home Care and Help at Home, Brussels.

Welschen P.T.M., Griffioen H.P., Manders P.J.C. \& Niebuhr T.M. (1990) Eindrapportage Functiewaarderingsonderzoek Gezinsverzorging (Final Report of the Job Evaluation Study in Home Help Services). LVT, Bunnik.

Windt van der W., Calsbeek H. \& Hingstman L. (1997) Verpleging En Verzorging in Kaart Gebracht (An Overview of Nursing and Caring). De Tijdstroom/LCVV, Utrecht.

Working Group (Werkgroep Werkveld) SOGW (1992) Beroepsprofiel Verzorgendel Helpende (Job profile Caring personnel). Spruyt, van Mantgem \& de Does BV, Leiden. 